\title{
Deconstructing Religion in Jeanette Winterson's Oranges Are not the Only Fruit: A Metacritical Study
}

\author{
Zaydun Al-Shara \\ Assistant Professor/ Literary Criticism \\ King Saud University \\ E-mail: zaydun72@yahoo.com
}

Doi:10.7575/aiac.alls.v.6n.1p.238

URL: http://dx.doi.org/10.7575/aiac.alls.v.6n.1p.238
Received: $16 / 10 / 2014$

Accepted: 04/01/2015

\begin{abstract}
The last few decades have witnessed an interesting new dimension in creative writing as a number of novelists have addressed literary theory in their literary texts, thus acting as creative metacritics. One intriguing writer who addresses theory in her fiction is the British novelist Jeanette Winterson. In this paper I intend to present Winterson as a creative metacritic of Deconstruction in her controversial novel Oranges Are Not the Only Fruit (1985). My argument is in two parts. First I present Winterson's treatment of religious texts, both Biblical and Quranic, in a manner that simulates Deconstructive critics when they interpret literary texts. I will show how Winterson uses her narrative to deconstruct religious beliefs and stories in order to open new possibilities of interpretations to replace these religious references. Next, I focus on Winterson's narrative and her intriguing use of embedded texts that function as interpretative riffs of the deconstructed religious texts. After rejecting the authority of religion and history as reliable sources of truth, she proposes other possibilities of interpretation that seem more realistic and more personal.
\end{abstract}

Keywords: Metacriticism, Structuralism, Deconstruction, Narratology, Embedded Texts

Jeanette Winterson, one of Britain's most prominent and controversial contemporary fiction writers, had a remarkable role in developing the role of metafictive novelists. According to Patricia Waugh in Metafiction: The Theory and Practice of Self-conscious Fiction (1988), metafiction is fiction which self-consciously and systematically draws attention to its status as artifact in order to pose questions about the relationship between fiction and realism (p. 2). Unlike other metafictive writers, whose major purpose is to "pose questions about the relationship between fiction and realism," Winterson, the creative metacritic, takes the role of a metacritic who overtly and/or covertly, through her fiction, responds to and critiques literary theory and scholarship. Her fictional work can be perceived as criticism of criticism. The experimental, metafictive novel allows Winterson to explore her philosophical convictions and theoretical analysis through self-referentiality and flexibility. Winterson brings together multiple creative and intellectual traditions, and, to use Italo Calvino's term from The Uses of Literature (1986), she can be classified as "philosopher-writer" (p. 39).

As an introduction, I like to make explicit some relevant ideas that explain the similarity between the narrator's relation with her community and between Deconstruction critics' relation with preceding literary approaches. Since Deconstruction is considered a revolutionary movement against traditional approaches of criticism, it is necessary to draw a comparison between Winterson's narrator's reaction to traditional social norms and traditional religious stories and between Deconstructionists treatment of conventional interpretations of literary texts.

Oranges Are Not the Only Fruit (1985) depicts the struggle of Jeanette, an adopted girl, raised by a fanatic Catholic woman and her passive husband. In spite of the difficulties Jeanette encounters while living with her non-biological mother, she manages to maintain a harmonic relationship with her family until her lesbianism is revealed in a religious community. In this novel, Winterson creates a chaotic atmosphere by bringing together two extreme situations. She chooses to deal with the narrator's homosexuality in a conservative surrounding in order to portray people's outrageous reactions that only emphasize their hypocrisy and irrationality and foreshadow Jeanette's mental and religious transformation.

In spite of the similarity between the author's biography and the narrator's story, the text cannot simply be seen as autobiographic. As Merja Makinen suggests in The Novels of Jeanette Winterson "Oranges Are Not the Only Fruit (2005) is more than just a realist autobiographical text" (p. 30). The speaking voice in the novel seems to reject the possibility of connecting the text to the author when she says, "Once created, the creature was separated from the creator, and needed no seconding to fully exist" (p. 46). In an interview Winterson stated that she does not like her readers to perceive Oranges are Not the Only Fruit as autobiographical. She objected to the way readers tried "to pin things down on a more concrete level" and delve into her personal life by saying: "This is not autobiography in the way that you understand it. It is simply a way of using raw material . . . because one always uses raw material from one's own life" (Bilger, interview 2011). 
Winterson chooses a character with unconventional behavior to introduce a revolutionary atmosphere. Susan Watkins contends that Jeanette's homosexuality in Oranges Are Not the Only Fruit is a rebellious act against normal social behavior (p. 154). Winterson deliberately creates this tension to emphasize the contradictory forces that constitute her narrative; the conventional religious community full of contradictions and the free-spirited narrator trying to define herself in the society. Winterson reveals her intention in creating an atmosphere of enmity by saying in "Rogue Elements" (1997):

I like to look at how people work together when they are put into stressful situations, when life stops being cozy, when it stops being predictable, when there is a chance element which unsettles all the rules which forces people back into their own resources, and away from their habits. You see it more often with animal behavior: They're all fine until you introduce some rogue element into the cage, and then they all go crazy. (p. 2)

This same philosophy can be discerned in Winterson's metacritical fiction:

What constitutes a problem is not the thing, or the environment where we find the thing, but the conjunction of the two; something unexpected in a usual place (our favourite aunt in our favourite porker parlor ) or something usual in an unexpected place (our favourite poker in our favourite aunt). (p. 5)

Homoerotic tendency results in a conflict between the vulnerable and sensitive Jeanette and the supposedly religious society that is insensitive and ruthless in response. The social confrontation that Winterson exposes her narrator to early in the novel is of great significance since it intensifies readers' sympathy towards Jeanette and also gives her a reason to reject these people and their religion. The heroine's conspicuous purity and naivety are carefully portrayed. With apparent modesty, Jeanette describes how on "one Sunday the pastor told everyone how full of the spirit [she] was" (p. 24) after she dedicated much of her time and effort to serve the church. Her loyalty to the church and its members does not protect Jeanette's dignity and emotions once her lesbianism is revealed. Winterson stigmatizes the criteria that these people depend on to determine good or evil. According to Jeanette's mother, goodness and evil depend on sexual desires (p. 3), in contrast with Jeanette who believes that decency, kindness, modesty and authentic faith determine goodness.

It seems that Winterson believes that there is no evil in Jeanette's sexual tendency. Unlike Jago Morrison (2003) who believes that Jeanette imagines her lesbian sexuality as a seductive demon (p. 97), Winterson looks upon her major character's lesbianism from a romantic perspective, not as a sin that should be fought back. And certainly, the religious atmosphere supports Winterson's message in intensifying the cruelty and hypocrisy of the members of the church who claim to be religious, but in fact are far from the real essence of religion. Winterson's heroine, as an honest and a good character, provides a counterpoint to deconstruct traditional religion and suggests a religion without hypocrisy and deception. As Doreen D'Cruz (2003) contends in her Loving Subjects, Jeanette creates her "own Bible of desire" (p. 167 ) and establishes a strong relationship between lesbianism and innocence.

As a matter of fact, Winterson's depiction of Jeanette's aversion to join the crowd is apparent after Jeanette's disappointment with people's hypocritical and outrageous reaction towards her homosexuality. She does "miss God", but because of the people who use his name to hurt her and mould her character, Jeanette drifts from his realm. Makinen (2005) explains that the "success of the novel is that it has us laughing about things we realise should make us weep as the character is forced, in order to preserve her integrity, to mock the sacred" (p. 5). Apparently, Jeanette is a romantic person who celebrates individualism and enhances the role of her heart and mind which are capable of understanding the world around her. Her search for alternatives can be perceived as a first step to deconstructing religion.

Winterson understands that religion does not necessarily follow logic or reason, though its effects on perceptions and decisions are undeniable. Winterson in "Imagination and Reality" (2005) argues that religion plays an important role in affecting individuals' perception of the real world. She explains that religion, unlike science, is capable of persuading people to believe the existence of what they cannot see, touch, or hear (p. 247). Intriguingly, Winterson's protagonist in Oranges Are Not the Only Fruit (1985) is quite the opposite. She depends on her perception of the real world that stems from her different personal experiences in order to redefine her religious beliefs. Apparently, Winterson's major character, Jeanette, realizes that she ought to redefine her religious beliefs after the dire circumstances she has been through caused by religious hypocrisy and ruthlessness. As a creative metacritic, Winterson uses her fiction to alert us to the risk of abusing the "imagining powers" of interpreting and redefining religious/narrative texts. Winterson is aware of the significance of understanding the real essence of religion before rejecting or finding flaws in it. Winterson infuses this idea in the "Ruth" chapter as she creates an intriguing analogy between the Wizard and the narrator's mother who were both eager to involve the two characters in their spiritual arts. In the primary text, Jeanette's mother wants to involve her in religion in order to become an active member in the church. In the embedded text, the Wizard wants to teach Winnet sorcery in order to become one of the few wizards left in the world. Through the voice of Winnet, who also reflects Jeannette's voice, Winterson alludes to the danger of deconstructing and modifying the original. The narrator in the embedded story says:

It's not possible to change anything until you understand the substance of the thing you wish to change. Of course people mutilate and modify, but these are fallen powers, and to change something you do not understand is the true nature of evil. (p. 141) 
As a metacritic, Winterson uses the same techniques that deconstruction critics use when they critique literary texts. In Literary Criticism (2007), Charles E. Bressler defines deconstruction as an "approach or strategy for reading... to discover "how" a text means by asking a different set of questions than Structuralist critics. Its aim is to show what a text claims it says and what it actually says are discernibly different" (p. 338). And "denying any center of truth, such as God, humanity, or the self, deconstruction maintains that we can never be certain about our values, beliefs, and assumptions. If this is the case, then we can never be certain about a text's meaning, and we can therefore never declare a text to have but one meaning. The "undecidability' of a text's meaning is the cardinal role of Deconstruction" (p. 337). Similarly, Winterson adopts one of the basic beliefs of Deconstruction which is the distinction between science and literary texts. Deconstructionists believe that science alone can provide truth unlike literature which is characterized by the uncertainty and undecidability of a text's meaning. Similarly, Winterson treats religious stories, whether Biblical or Quranic, as if they are literary texts that can be doubted and deconstructed, denying any center of truth for these religious texts. Winterson reveals her deconstructive approach in reading religious texts through her heroin's conversation with her orange demon. When she told the demon that "in the Bible [he keeps] getting driven out," the demon's instant reply was "Don't believe all you read" (p. 109).

Intriguingly, Winterson does not depend on other authorities and figures to interpret these Biblical and historical contexts. In fact, she insists that she is the most eligible and dependable person to reach an interpretation. She alludes to this idea in her novel when she discusses the possibility of multiple interpretations of historical and literary texts due to the various intentions of the people who narrate these stories. In "Deuteronomy" chapter she says:

And when I look at a history book and think of the imaginative effort it has taken to squeeze this oozing world between two boards and typist, I am astonished. Perhaps the event has an unassailable truth. God saw it. God knows it. But I am not God. And so when someone tells me what they heard or saw, I believe them, and I believe their friend who also saw, but not in the same way, and I can put these accounts together and I will not have a seamless wonder but a sandwich laced with mustered of my own ... If you want to keep your own teeth, make your own sandwiches. (p. 95)

It could be inferred that Winterson supports the notion of the incredibility of narrative texts. In fact she agrees with Jacques Derrida's assertion in Writing and Difference (1978) that the entire history of the West is based on an error.

This is why one perhaps could say that the movement of any archaeology, like that of any eschatology, is an accomplice of this reduction of the structurality of structure and always attempts to conceive of structure on the basis of a full presence which is beyond play.

If this is so, the entire history of the concept of structure, before the rupture of which we are speaking, must be thought of as a series of substitutions of center for center, as a linked chain of determinations of the center. Successively, and in a regulated fashion, the center receives different forms or names. The history of metaphysics, like the history of the West, is the history of these metaphors and metonymies. (p. 353)

This rejection of absolute truth encourages revolutionary and independent individuals, such as Winterson, to deconstruct what has already been built. After deconstructing these texts, Winterson reveals the contradictory meanings that exist beyond the literal meaning of religious stories. And she adeptly provides these particular stories new interpretations that stem from her personal experience and are thus more realistic and more convincing.

Apparently, Winterson is dissatisfied with the version of reality that religion presents. To her, religion seems ideal and supernatural and the solutions it offers to individuals appear in the form of miracles from God. In the religious stories that Jeanette learned in the church, God is merciful and generous to his people. God rewards these people for their good deeds and punishes his enemies for their evilness and hypocrisy. Yet the God Jeanette knows in Oranges Are Not the Only Fruit (1985), seems merciless and oblivious to her suffering. He lets her down and deprives her from the salvation he promised his good servants for their good deeds.

Winterson reveals her narrator's frustration and bitterness towards her God when she associates Jeanette with the Biblical story of Moses on Mount Nebo. According to religious texts, Moses and his people were forced to leave Egypt and to head towards Jerusalem for refuge. On the way, Moses' people turn against him and blame him and his God for their starvation and thirst. In the midst of his despair and sense of betrayal by his people, Moses hits the stone and divine water flows out of it. In the novel, Winterson makes an analogy between Moses' despair and sense of betrayal by his people and Jeanette's frustration when she was kicked out of her mother's house and rejected by the members of the church. The analogy between the two stories is depicted through Jeanette's cynical implication when she says:

I was in trouble. Picking up my bible, the hill seemed the only place to go just then. On the top of the hill is a stone mound to hide behind when the wind blows. The dog never worked it out; used to pee against, or to play hide and seek with me, but still stood ears flattered and water- eyed till I slung her up in my jacket and warming both of us. (p. 127)

Unlike Moses who was saved by God's mercy, Winterson reflects a brutal reality that deprives her modern anti-heroine from God's blessings since no sign of salvation sent from God. Instead she only finds her dog's urine. Unfortunately, 
the modern God does not compensate Jeanette for her loss of home and sense of security; he deserts her as her mother and the church did.

Another example that illustrates Winterson's reinterpretation of Biblical stories takes place when she takes the role of Jesus Christ. As Jesus sacrifices his life to save humanity from their sins, Jeanette sacrifices her reputation and security to save Katy by taking all the blame. Although Katy is as guilty as Jeanette in violating the church's sanctity when they are both caught having sex, Jeanette decides to take the responsibility on herself and endure the punishment and the humiliation in order to save the person she cares for. But unlike the Biblical story of Jesus, Jeanette does not sacrifice herself to wash away her sins. On the contrary, by this bold behavior she only emphasizes her clinging to what is religiously considered as a sin.

Perhaps, the most important association in Winterson's Oranges Are Not the Only Fruit (1985) is the title with the Biblical story of Adam and Eve and the original sin. As it appears in the short story of the secret garden on the banks of the Eupharates, Winterson draws a clear and direct connection to Adam and Eve and the Lost Paradise. Religiously speaking, it is not known whether the forbidden fruit is an apple, an orange or any other kind of fruit. So this gives Winterson an opportunity to invent her own version. Here Winterson attempts to explain that this forbidden fruit is only symbolic; it might be an apple, a banana or even a cherry but not necessarily an orange. In other words, to follow one's own heart and try to fulfill his or her personal desires in this life, which is governed by many religious and social strictures, will expose a person to great danger and make him or her an outsider. Jeanette says:

All true quests end in this garden, where the split fruit pours forth blood and the halved fruit is a full bowl for travellers and pilgrims. To eat from this fruit means to leave the garden because the fruit speaks of other things, other longings. (p. 123)

The fruit, in this context, is Jeanette and her lesbianism is violating the strict orders to stay away from the fruit. That is why Jeanette describes her ex-girlfriend, Melanie, when she gets married as a vegetable; and, of course, eating vegetable is not forbidden according to the story of the Original Sin.

Temptation creates a major dilemma in Winterson's Oranges Are Not the Only Fruit (1985), and fighting lesbianism for Jeanette is not an easy task. She is fully aware of the vile consequences of her sexual tendency, considered as a sexual deviation according to people's perception of her case. And Winterson, too, is aware of the danger of the impact of society on her heroine. It is unknown how much Winterson is familiar with Islam and the Holy Quran, but there is a strong association between Jeanette's brown pebble and the small pebbles in Islamic culture. According to Islamic culture, when Muslim pilgrims pilgrimage to Mecca they have to perform a certain ritual at the end of their spiritual journey; they are to throw twenty-one small brown pebbles at a symbolic column that represents Satan. What enhances this assumption, the connection between Jeanette's brown pebble and the Muslim pilgrims' pebbles, is the reference to the Holy Dice that Elsie bought from Mecca forty-years ago and their discussion about the Holy Spirit (p. 32). And also, the raven according to the Quran is Satan's advocate who inspired Cane to kill his brother, Able, and bury him when the former felt jealous because his brother married the beautiful sister; since there were only two brothers and two sisters, each male had to marry the other female in order to save human race from distinction. Similarly, the role of the raven in the sorcerer's tale is to illuminate Winette by revealing the sorcerer's secret that she will never lose the skill she learnt. And also Winterson's heroine is inspired to come up with a plan to rescue her girlfriend; since "[she] promised her to ... think of something. They did. The plan was the most fanciful of [her] brilliant career and from [Katy's] point of view it worked" (p. 129). The irony in Winterson's novel is that evil stems from the members of the church, Jeanette's real enemies, and not from Satan. So, when she is approaching the point where she decides to throw her society with the small pebble becomes rougher and rougher, and the demon becomes Jeanette's advocate against her people. According to her dream, she seems to negotiate the demon whether it is worth keeping him in spite of the complications that might arise from their compact. Jeanette Confesses:

When I sat down the demon was glowing very bright and polishing the crocodile with its

Handkerchief.

'What sex are you?'

'Doesn't matter does it? After all that's your problem.'

'If I keep you, what will happen?'

'You'll have a difficult, different time'

'Is it worth it?'

'That's up to you.' (p. 190)

Since the modern God is no longer capable of bringing salvation to his people, and the stories that religion presents do not reflect human reality, Winterson realizes that she ought to create her "own Bible". Winterson, in Oranges Are Not the Only Fruit (1985), creates stories within her novel to simulate the Biblical stories that are passed down from religious people. But the difference between these Biblical stories and the stories she invents is that her version is more realistic and more capable of reflecting her agony and the disarray that humanity is heading to. In The Modern Novel (2004), Jesse Matz explains that Winterson in Oranges Are Not the Only Fruit (1985) intends to create better realities 
through writing a hybrid of a religious and erotic discourse (p. 167). I would like to add that Winterson's treatment of her interstories (or embedded texts) is an attempt to replace these religious texts that seem far from reality with other narratives that reflect her major character's situation. Indeed, the embedded texts function as a mirror for Jeanette's life. According to Mieke Bal in Narratololgy (2004),

When the primary fabula and the embedded fabula can be paraphrased in such a manner that both paraphrases have one or more elements in common, the subtext is a sign of the primary text. The place of the embedded text- the mirror-text - in the primary text determines its function for the reader. When the mirror-text occurs near the beginning, the reader may, on the basis of the mirror-text, predict the end of the primary fabula. In order to maintain suspense, the resemblance is often veiled. The embedded text will only be interpreted as mirror-text and 'give away' the outcome when the reader is able to capture the partial resemblance through abstraction. That abstraction resemblance, however, is usually only captured after the end, when we know the outcome. Thus suspense is maintained, but the prefiguring effect of the mirror-text is lost. (p. 58)

Although Winterson is not a pioneer in using embedded texts in literature, her use of this narrative technique is particularly interesting. As Winterson employs the embedded texts inside each other her novel functions like a set of Babushka dolls. Fairy tales and historical stories are embedded in Jeanette's narrative, and then these again are embedded as fairy tales and historical stories along with Jeanette's narrative in eight Chapters from the Bible. Winterson's other compelling narrative technique is in her treatment of certain Biblical stories that do not stand separately as independent stories, but are implied in the text with great tact. The reader would only be able to connect these implied stories by revealing the relationship between Jeanette's actions and discourse and the general context of these actions and discourses.

The first and perhaps the most apparent primary text in Winterson's Oranges Are Not the Only Fruit (1985) is the Bible which she enfolds Jeanette's narrative. She chooses to use the eight Biblical Chapters in order to name the different stages of her major character's life. According to Peter Childs (2005), the eight Biblical Chapters that comprise Oranges Are Not the Only Fruit (1985) mirror Jeanette's life from the beginning in Genesis to the story conclusion on Christmas Day (p. 266). Apparently, the author is responsible for naming these chapters and not the narrator. This means that the story of the major character is separated in space and time from the Biblical context. In other words, Jeanette, the character and the narrator, is unaware of the implications of these Biblical names. At the same time, this technique gives the reader the notion that the content of these Chapters reflects these Biblical contexts; a technique that will intensify the reader's sense of irony, because Winterson replaces macrocosmic issues within a microcosmic experience. She does not only create her own Bible (p. 167), as Doreen D'Cruz contends in her Loving Subjects (2002), but also alludes to the idea of the unrealistic nature of Biblical stories in general. This does not necessarily mean that Winterson intends to doubt the credibility of the Bible, but she needs to assert that her major character's personal experience, agony and reality are more important than others' experiences.

One form of embedded texts in Winterson's novel is the literary allegorical embedded stories. This employment of the embedded texts is unique and calls for scrutiny on the reader's part, because Winterson does not simply create stories that stand independently. These stories can be distinguished through an allegorical interpretation of the characters' behaviors and utterances. For example, Jeanette's reference to A Streetcar Named Desire after her failure to please her teacher has an allegorical significance. Unlike Blanche Dubois in Tennessee Williams' play, Winterson's narrator is independent and persistent. Jeanette does not give up and does not accept what her fate has shown her. It is true that desire has led her to be considered an outsider in her own community, but she does not seem to regret sexual identity or even resist it. After she did not win the prize for doing her project on Easter, Jeanette says: "I didn't despair; I did Streetcar Named Desire" (p. 48).

Another form of the embedded texts is represented in the group of the independent stories that interrupt the main narrative. One of these stories that seems to reflect Jeanette's reality is the story of emperor Tetrahedron. The only way that Tetrahedron manages to survive death because of the fatigue caused by the performance of the midgets is by having many faces (p. 49). This story can be related to Jeanette's situation since she has to have different faces in order to avoid the sever threat that is imposed on her by her society due to her homosexuality. Often she is forced to hide her sexual identity in front of her mother and the church until she can depend on herself.

Susan Sellers in Myth and Fairy Tale in Contemporary Women's Fiction (2000) contends that Winterson, like other women writers, uses fairy tales and myth because their "procedures enable the expression of more individually resonant, less easily co-optable, multifarious truths" (p. 23). Since myth and fairy tales are people's own creation to explain or justify an individual's behaviors or feelings, Winterson, in Oranges Are not The Only Fruit (1985), invents certain tales and adopts others to reflect her heroine's personal problems and perspectives. These invented stories enrich the novel with multifarious themes and motifs on one hand, and on the other hand they give Winterson a chance to convey her ideas repeatedly without the monotony of repetition. In these invented inter-stories, Winterson symbolically portrays her major character's personal experience with the society. The reader cannot avoid drawing a strong analogy between Jeanette and the characters she creates in her embedded texts. Winterson depends on imaginative stories to explain and reflect her reality in an unrealistic way. She does not necessarily care for the truth of her invented stories as long as they serve her interest. She is a storyteller, and, according to Winterson, storytellers are most likely to alter facts and present them the way they perceive these facts. In "Deuteronomy" Chapter, Winterson contends that: 
Very often history is a means of denying the past. Denying the past is to refuse its integrity. To fit it, force it. Function it, to suck out the spirit until it looks the way you think it should. We are all historian in our small way. (pp. 93-4)

The other embedded story where Winterson embodies her major character's experience is the story of Winette and the sorcerer. Both Winette and Jeanette have fallen under supernatural spells which they struggle to escape. Jeanette, in the novel, tries to escape the religion forced on her by her mother that judges her sexual tendency. Similarly, Winnet is forced to learn the skill of sorcery, and the moment she defies the social norms by showing sexual interest in a boy, she is ostracized by her community and forced to leave the castle which she has taken as a permanent haven. The analogy created here is not only to show similarities between the two stories, but to launch a severe attack on religion which Winterson doubts and defies. Winterson considers religion a form of illusion that deludes people in the same way magic does.

Also through this analogy, Winterson reveals a lack of intimacy in people's relationships. Winnet realizes that if she gives her name to the sorcerer and allows him to enter the "chalk circle" (p. 143), she allows him to become intimate and, therefore, influence her emotionally, and perhaps hurt her if he abandons her. Hence, superstitiously speaking, the name is used to put a spell on someone, and the chalk circle is the symbolic personal zone that a person allows others to enter, based on the kind of relationship this person wants.

Another embedded story Winterson provides as a replacement of the Biblical stories is the Prince who seeks perfection. Winterson reveals another aspect of Jeanette's personality and reflects her despair and drastic need to find a perfect companion who is able to stand by her side and support her. Unfortunately, Jeanette and the Prince conclude that perfection is only an illusion, and that if there is perfection in this world, it is only temporary, determined by circumstances and personal interests. Jeanette expresses her attitude towards these two ideas, the power of names and perfection, in one quotation at the end of the novel when she says:

As it is, I can't settle, I want someone who is fierce and will love me until death and know that love is strong as death, and be on my side forever and ever. I want someone who will destroy and be destroyed by me. There are many forms of love and affection, some people can spend their whole lives together without knowing each other's names. Naming is a difficult and time consuming process; it concerns essence, and it means power. But on the wild nights who can call you home? Only the one who knows your name. (p. 170)

Unfortunately, Winterson's narrator believes that loyalty and eternal love are unattainable because betrayal existed in human beings in the past as well as in the future as she emphasizes this credence in her treatment of the historical story of King Arthur, the third embedded text treated by Winterson in the novel. Winterson intensifies Jeanette's sense of betrayal further by associating her love disappointment with the legendary King Arthur who also suffered from his wife's betrayal. Jeanette tries to console herself by believing that she is not the only person betrayed by a beloved. Even the most powerful figures are susceptible to emotional pain and disappointment. She bitterly asserts:

The Round Table and the high-walled castle were almost symbols now. Once they were meat and drink. But for Launcelot and Bors, betrayal is in the future as well as in the past. Launcelot is gone, driven mad by heavy things. (pp. 128-9)

Winterson's introduction of the historical story of King Arthur in her novel is a reflection of her major character's reality and not a construction of the events of the story. The role of history seems so simple and direct, a reminder of a previous event that is similar to a current one. Ironically, Winterson's choice of the story of King Arthur to reflect her narrator's reality causes perplexity. It is well known that although the character of King Arthur is real, many of the stories that are told about him are legends and invented stories produced by Celtic, English and French cultures. Winterson chooses this legend in order to support her perception of historical texts. Perhaps, Mark Currie best sums up Winterson's attitude toward historical texts in Postmodern Narrative Theory (1998).

Greenblatt argues that history has to renew itself by moving away from 'realist' assumptions about the meaning of a historical text towards a recognition that history and literature are discourses which construct rather than reflect, invent rather than discover the past. (p. 88)

Apparently, the fairy tales and the historical story in the novel are symbolic reflections of either incidents happened to Jeanette, or deep hidden desires and convections that dwell in her heart and mind. Winterson's choice of these symbolic inter-stories serves as an aesthetic style to fill the gaps that she creates in her novel when she deconstructs the Biblical stories by rejecting the interpretations that were passed down by religious institutions.

I conclude by emphasizing that when Winterson deconstructs religious stories, she does not impose her own interpretation on the reader. She only reflects her own interpretation that stems from her personal understanding of life and people's relationships. As a matter of fact, she does believe that people have different beliefs and religions. But what she is eager to criticize in Oranges Are Not the Only Fruit (1985) is close-mindedness and hypocrisy. Winterson alludes to the diversity of convictions through Jeanette's description of her mother when they disagree over their 
opinions. Jeanette says about her mother that "she was wrong, as far as [they] were concerned, but right as far she was concerned, and really, that's what mattered" (p. 5). But when Winterson realizes that her sexual identity is not accepted by her religious community, she decides to deconstruct their religious stories and invent her own version.

\section{References}

Bal, M. (2004). Narratololgy: Introduction to the theory of narrative. Toronto: $U$ of Toronto P.

Bressler, C. (2007). Literary criticism: An introduction to the theory and practice. New Jersey: Pearson.

Calvino, I. (1986). Philosophy and literature. The uses of literature. Harcourt Barce Jovanovich: New York.

Childs, P. (2005) Contemporary novelists: British fiction since 1971. New York: Plagrave.

Currie, M. (1998) Postmodern narrative theory. New York, NY: Palgrave.

D’Cruz, D. (2002). Loving subjects: Narratives of female desire. New York, NY: Peter Lang Publishers.

Derrida, J. (1978). Structure, sign, and play in the discourse of the human sciences. Writing and difference. Trans. Alan Bass. Chicago, IL: U of Chicago P.

Makinen, M. (2005). The novels of Jeanette Winterson. England: Palgrave Macmillan.

Matz, J. (2004). The modern novel: A short introduction. Oxford: Blackwell.

Morrison, J. (2003). Contemporary fiction. London: Routledge.

Sellers, S. (2000). Myth and fairy tale in contemporary women's fiction. New York, NY: Plagrave.

Waltkins, S. (2001). Twentieth-century women novelists: Feminism theory into practice. New York, NY: Palgrave.

Waugh, P. (1988). Metafiction: The theory and practice of self-conscious fiction, New York, NY: Routledge.

Winterson.(2005). Imagination and reality. Everyday theory: A contemporary reader. Ed. Becky McLaughlin and Bob Coleman. New York, NY: Longman.

----- (2011). Interview with Audrey Bilger The art of fiction No. 150. The Paris Review

http://www.theparisreview.org/interviews/1188/the-art-of-fiction-no-150-jeanette-winterson

----- (1985). Oranges are not the only fruit. New York, NY: Grove P.

(1997). Rogue elements. http://archive.salon.com/april97/winterson970428.html 